\title{
Color Change and Resistance to Subterranean Termite Attack of Mangium (Acacia mangium) and Sengon (Falcataria moluccana) Smoked Wood $^{1}$
}

\author{
Yusuf Sudo HADI ${ }^{2, \dagger} \cdot$ Muh Yusram MASSIJAYA ${ }^{2} \cdot$ Imam Busyra ABDILLAH $^{2}$ • \\ Gustan $\mathrm{PARI}^{3} \cdot$ Wa Ode Muliastuty $\mathrm{ARSYAD}^{3}$
}

\begin{abstract}
Indonesian log production is dominated by young trees harvested from plantation forests. The timber contains of sapwood and juvenile wood, which are not resistant to termite attack. Smoking treatment can enhance wood resistance to termite attack, but it also changes the color. Specimens of mangium (Acacia mangium) and sengon (Falcataria moluccana) wood were exposed for 1, 2, and 3 weeks to smoke produced from the pyrolysis of salam (Syzygium polyanthum) wood. The color change of the wood was measured using the CIELab method. In addition, wood specimens were exposed to subterranean termites (Coptotermes curvignathus Holmgren) under laboratory conditions. Untreated and imidacloprid-preserved wood samples were also prepared for comparison purposes. The results showed that the color of smoked wood differed from that of untreated wood, and the color change for sengon was greater than for mangium. In addition, the 1-week smoking period changed the wood color less than the 2- and 3-week periods, which did not differ. Imidacloprid-preserved wood had distinctive color changes compared to untreated wood. Untreated mangium wood had moderate resistance to subterranean termite attack (resistance class III), while sengon had very poor resistance (resistance class V). Salam wood smoke enhanced wood resistance to termite attack, and smoke treatment of 1 week for mangium and 2 weeks for sengon resulted in the wood becoming very resistant (resistance class I). Both types of smoked wood were more resistant to subterranean termite attack than imidacloprid-preserved wood (average class II resistance).
\end{abstract}

Keywords: smoked wood, wood color change, subterranean termite attack, termite resistance class

\section{INTRODUCTION}

The Indonesian wood industry processed 43 million $\mathrm{m}^{3}$ of logs in 2017 , and $87 \%$ of the wood was harvested from plantation forests with a total area of 11.1 million ha (Ministry of Environment and Forestry, 2018).
Fast-growing tree species,such as mangium (Acacia mangium) and sengon (Falcataria moluccana), are commonly planted to achieve a short cutting rotation, typically only 6 to 10 years. Fajriani et al. (2013) reported that wood from young plantation forests was dominated with sapwood and containing juvenile wood,

\footnotetext{
${ }^{1}$ Date Received May 12, 2019, Date Accepted August 28, 2019

2 IPB University (Bogor Agricultural University), Bogor 16680, Indonesia

${ }^{3}$ Forest Products Research and Development Centre, Bogor 16610, Indonesia

† Corresponding author: Yusuf Sudo HADI (e-mail: yshadi@indo.net.id, ORCID: 0000-0002-2212-4501)
} 
which have low physical-mechanical properties and low resistance to bio-deterioration due to attack by insects and other organisms. Production of better physicalmechanical properties and resistance to bio-deterioration by organisms, including termites, requires ongoing development of methods to improve wood quality.

Previous investigations have explored quality improvements of wood from young forest stands. To improvephysical-mechanical properties, wood has been used to manufacture glued laminated lumber (glulam) (Komariah et al., 2015; Lestari et al., 2018), laminated composite panel (Hendrik et al., 2016), and methyl methacrylate impregnated wood (Hadi et al., 2013; 2019). To lengthen the service life of wood or make it more resistant to bio-deterioration attack without preservative agents, chemically modifications have been used to produce furfurylated wood (Hadi et al., 2005) and acetylated wood (Hadi et al., 2015). In addition, impregnating plastic into wood void has yielded polystyrene-impregnated wood (Hadi et al., 2016b), methyl methacrylate-impregnated wood (Hadi et al., 2018), and acetylated rubber-wood flakeboard (Hadi et al., 1995).

Smoke treatment of wood has also been investigated to preserve both wood (Hadi et al., 2012) and glulam (Hadi et al., 2016a). Smoking has long been used in the food industry to extend product shelf life, provide flavor, and change the color of food products (Toledo, 2008). Smoke from wood contains a large number of polycyclic aromatic hydrocarbons, which are predominantly phenols, aldehydes, ketones, organic acids, alcohols, esters, hydrocarbons, and various heterocyclic compounds (Stołyhwo and Sikorski, 2005).

Various techniques exist for smoking products. Hot smoking combines drying and smoking by holding the temperature in the chamber at $55-80{ }^{\circ} \mathrm{C}$, while cold smoking and warm smoking are single purpose processes with the chamber temperature held at $15-25{ }^{\circ} \mathrm{C}$ or $25-45{ }^{\circ} \mathrm{C}$, respectively (Stołyhwo and Sikorski,
2005). Ishiguri et al. (2001, 2003) applied hot smoking to wood, which resulted in changes to color and moisture content and also produced surface checks on the wood when the process extended over a long period. The color change usually resulted in darker wood, as reported by Hidayat et al. (2017). In their study, heat treatment of Korean white pine and royal paulownia wood resulted in darker colors compared with untreated wood, and consumers preferred the darker shades over the lighter color. In terms of tar, the substrate occurs as a byproduct in charcoal kilns (Yang et al., 2017) and it could give wood a black color, but the color change would not be appealing for furniture components.

To determine the effect of smoke on wood resistance to bio-deterioration attack, cold smoking was more sharply giving needed information. This work was undertaken by Hadi et al. (2010, 2016a) on mindi (Melia azedarach), sengon (Falcataria moluccana), sugi (Cryptomeria japonica), and pulai (Alstonia sp.) wood as well as glulam from fast-growing wood species. Overall, the results showed that cold smoking improved wood resistance against termite attacks. Furthermore, Hadi et al.(2016a) reported that smoke from mangium wood contains chemical compounds such as acetic acid, cyclobutanol, phenolic compounds and other polycyclic aromatic hydrocarbons. Smoke produced from other wood species may have different chemical compounds (Toledo, 2008).

Salam wood (Syzygium polyanthum) has a medium specific gravity and a high number of chemical compounds, especially extractive (Martawijaya et al 2004 did not say the volatile substance, but the extractive only) substances (Martawijaya et al., 2004). It can be processed for charcoal production, and the smoke produced as a byproduct could be used in the smoking process of wood. The purpose of the current study was to determine how does salam wood smoke change the color of mangium and sengon woods after one-, two-, and three-week smoking treatments, and also the 
Color Change and Resistance to Subterranean Termite Attack of Mangium (Acacia mangium) and Sengon (Falcataria moluccana) Smoked Wood

resistance of smoked woods to subterranean termite attack. Imidacloprid-preserved wood was also prepared for comparative purposes.

\section{MATERIALS and METHODS}

\subsection{Wood preparation}

Mangium and sengon were harvested in Bogor, West Java, Indonesia, and wood samples were used for smoked wood experiments. The densities of mangium and sengon wood were $0.56 \pm 0.02$ and $0.36 \pm 0.03$ $\mathrm{g} / \mathrm{cm}^{3}$, respectively. The measured responses were color changes according to Hunter Lab (1996) and resistance to subterranean termite attack in laboratory tests according to Indonesian standard SNI 7207-2014 (SNI, 2014). Wood was cut into specimens of $0.5 \times 2.5 \mathrm{~cm}$ in cross section by $2.5 \mathrm{~cm}$ in the longitudinal direction for the testing. Wood specimens were divided into three categories: untreated wood, smoked wood, and imidacloprid-preserved wood. Salam wood was pyrolyzed to produce charcoal, and the smoke released as a byproduct was used for the smoking process, which lasted 1, 2, and 3 weeks (Hadi et al., 2010).

For analysis of the chemical compounds of the smoke, condensed smoke, or wood vinegar before entering the smoking chamber, was analyzed by gas chromatography -mass spectrometry (GC-MS). For purposes of comparison, wood preserved with imidacloprid 3\% was also prepared. The samples were dried to reach $12 \%$ moisture content, weighed, and then placed under vacuum at 5 atmospheres for 30 minutes and pressure at 5 atmospheres for 30 minutes (Hadi et al., 2018). The samples then underwent conditioning for 2 weeks. Five replications were done for each treatment.

\subsection{Wood color change determination}

The CIELab method was using to determine wood color. This method involved directly measuring the values of $\mathrm{L}^{*}, \mathrm{a}^{*}$, and $\mathrm{b}^{*}$ from a photograph (which was obtained from scanning with CanonScan 4400F) of the wood sample with the Adobe Photoshop CS5 application. $\mathrm{L}^{*}$ indicated lightness, with a value of 0 to 100 (black to white); a* indicated colors from green to red, with $+\mathrm{a}^{*}$ from 0 to 80 corresponding to red and $-\mathrm{a}^{*}$ from -80 to 0 corresponding to green; and $\mathrm{b}^{*}$ indicated color from blue to yellow, with $+\mathrm{b}^{*}$ from 0 to 70 corresponding to yellow and $-b^{*}$ from -70 to 0 corresponding to blue (Christie, 2007). Each sample was assessed at five points, and the average values were used in the analysis. The color change $(\Delta \mathrm{E})$ was calculated regarding to CIELab (Hunter Lab, 1996), using the following equation:

$$
\Delta E=\sqrt{\left[(\Delta L)^{2}+(\Delta a)^{2}+(\Delta b)^{2}\right]}
$$

where

$\Delta E=$ color change

$\Delta L=$ difference in $\mathrm{L}$ values between compared samples

$\Delta a=$ difference in a valuesbetween compared samples

$\Delta b=$ difference in $\mathrm{b}$ values between compared samples

According to Hunter Lab (1996) and Hrčková et al.(2018), color change can be classified as shown in Table 1.

Table 1. Color change classification

\begin{tabular}{ccl}
\hline Class & Color difference & \multicolumn{1}{c}{ Color change effect } \\
\hline \hline 1 & \multicolumn{1}{c}{$\Delta E<0.2$} & Invisible changes \\
2 & $0.2<\Delta E<2.0$ & Very small changes \\
3 & $2.0<\Delta E<3.0$ & $\begin{array}{l}\text { Small changes (color } \\
\text { changes visible by } \\
\text { high-quality filter) }\end{array}$ \\
& $3.0<\Delta E<6.0$ & $\begin{array}{l}\text { Medium (color changes } \\
\text { visible by edium-quality } \\
\text { filter) }\end{array}$ \\
5 & $6.0<\Delta E<12$ & $\begin{array}{l}\text { Big (distinct color } \\
\text { changes) } \\
\text { Different color }\end{array}$ \\
6 & $\Delta E>12$ &
\end{tabular}


Yusuf Sudo HADI • Muh Yusram MASSIJAYA • Imam Busyra ABDILLAH • Gustan PARI • Wa Ode Muliastuty ARSYAD

\subsection{Subterranean termite test}

The laboratory subterranean termite test was based on Indonesian standard SNI 7207-2014. Each test specimen was placed in a glass container with $200 \mathrm{~g}$ of sterilized sand, $50 \mathrm{~mL}$ of water, and 200 healthy and active workers of Coptotermes curvignathus subterranean termites from a laboratory colony. The containers were put in a dark room at a temperature of $25{ }^{\circ} \mathrm{C}$ to $30{ }^{\circ} \mathrm{C}$ and $80 \%$ to $90 \%$ relative humidity for 4 weeks and weighed weekly. If the moisture content of the sand decreased by $2 \%$ or more, water was added to achieve a $25 \%$ moisture content. At the end of the 4-week test, the wood samples were oven-dried. Wood weight loss and termite mortality were determined using the following formulae:

Weight loss $(\mathrm{WL})=(\mathrm{W} 1-\mathrm{W} 2) / \mathrm{W} 1 \times 100 \%$

where W1 is the weight (g) of oven-dried samples before the test, and W2 is the weight (g) of oven-dried samples after the test.

Termite mortality $=(\mathrm{T} 1-\mathrm{T} 2) / \mathrm{T} 1 \times 100 \%$

where $\mathrm{T} 1$ is the number of live termites before the test, and $\mathrm{T} 2$ is the number of live termites after the test.

We assumed that termites died linearly with time, and we calculated the feeding rate according to the following equation:

$$
\begin{aligned}
& \text { Feeding rate (FR) ( } \mu \mathrm{g} / \text { termite/day) } \\
& \text { = (weight of wood eaten; } \mu \mathrm{g}) / \\
& \text { (average number of living termites)/ } \\
& \text { (number of days in the test period) }
\end{aligned}
$$

Wood resistance class against subterranean termites was determined by referring to SNI 7207-2014 as shown in Table 2.
Table 2. Resistance class against subterranean termite

\begin{tabular}{ccc}
\hline Resistance class & Sample condition & Mass loss (\%) \\
\hline \hline I & Very resistant & $<3.52$ \\
II & Resistant & $3.52-7.50$ \\
III & $\begin{array}{c}\text { Moderately } \\
\text { resistant }\end{array}$ & $7.50-10.96$ \\
& Poorly resistant & $10.96-18.94$ \\
IV & Very poorly & $>18.94$ \\
V & resistant & \\
& &
\end{tabular}

\subsection{Data analysis}

To analyze the effect of treatments upon all responses, i.e. color change, weight loss, mortality, and feeding rate, a $2 \times 5$ factorial in completely randomized design was used for data analysis. The first factor was wood species (mangium and sengon), and the second factor was treatment (untreated, smoke 1 week, smoke 2 weeks, smoke 3 weeks, and imidacloprid preservation). Duncan's multiple range test was used for further analysis if a factor was significantly different at $\mathrm{p} \leq$ 0.05 .

\section{RESULTS and DISCUSSION}

\subsection{Chemical compounds in salam liquid smoke}

The GC-MS analysis showed that the dominant chemical compounds of salam liquid smoke were acetic acid, followed by phenol, ketone, benzene, aldehyde, and other compounds. Compared with the findings of Hadi et al. (2016a), the dominant chemical compounds and their relative percentages differed from those of mangium smoke, which consisted of acetic acid, cyclobutanol, acetone, and phenol. These results indicate that different types of wood produce different smoke compounds, confirming results reported by Toledo (2008). Both types of smoke had similar dominant com- 


\section{Sengon Wood}

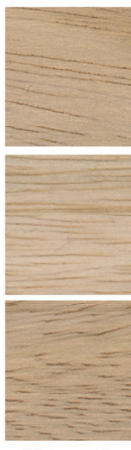

Untreated

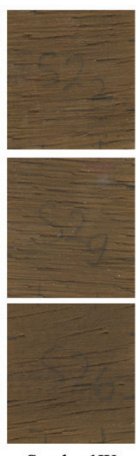

Somke-1W

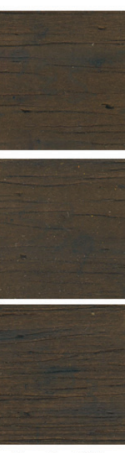

Smoke-2W

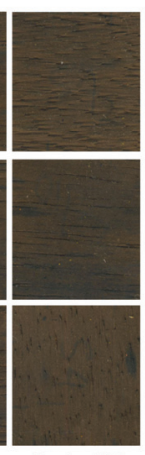

Smoke-3W

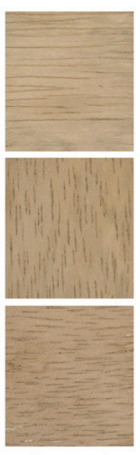

Preserved

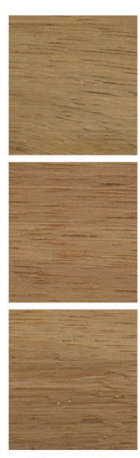

Untreated
Mangium Wood

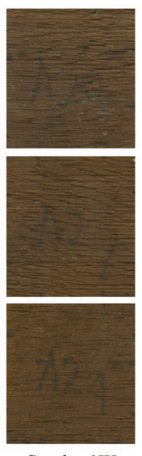

Smoke-1W

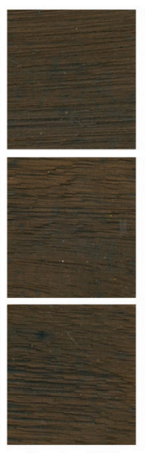

Smoke-2W

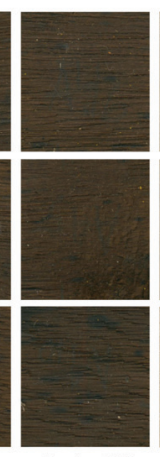

Smoke-3W

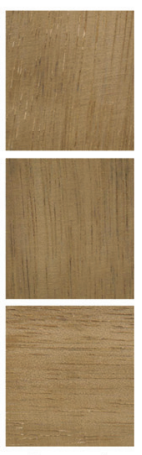

Preserved

Fig. 1. The color of wood specimens before and after smoking or imidacloprid preservation.

pounds, however, particularly acetic acid, phenol, and acetone. Phenolic compounds and acetic acid were previously shown to be effective as wood preservatives against termite attack (Yang et al., 2016), and it was also reported that smoke can be utilized to protect wood against attack by fungi, termites, and bacteria.

\subsection{Wood color change}

The colors of mangium and sengon wood that was untreated, smoked 1, 2, or 3 weeks ( $1 \mathrm{~W}, 2 \mathrm{~W}, 3 \mathrm{~W}$, respectively), or preserved with imidacloprid are shown in Fig. 1. The values of $\mathrm{L}^{*}, \mathrm{a}^{*}, \mathrm{~b}^{*}$, and $\mathrm{A} E$ are presented in Figs. 2, 3, 4 and 5, respectively, with the legends Smoke-1W means smoking process for 1 week, Smoke-2W means smoking process for 2 weeks, Smoke-3W means smoking process for 3 weeks, and Preserved means preservation with imidacloprid .

As shown in Fig. 5, the color change $(\Delta \mathrm{E})$ values of smoked wood were more than 12 points and consequently indicated that the wood was a different color from untreated wood (Table 1). The color change values of imidacloprid-preserved wood were between 6 to 12 points, indicating distinct color changes from untreated wood. Based on analysis of variance in Table 3, color change was affected very significantly by wood species,

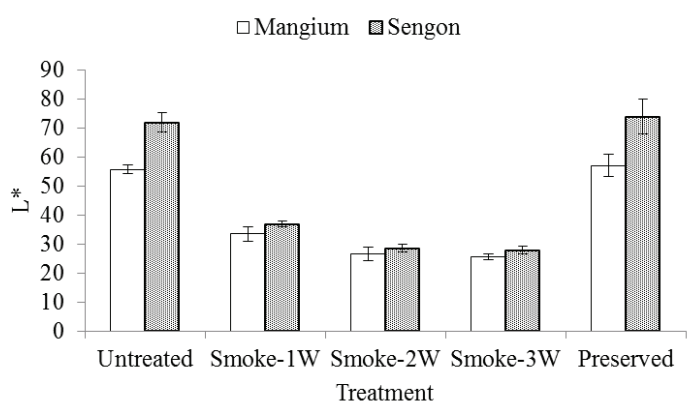

Fig. 2. The $\mathrm{L}^{*}$ (lightness) values of mangium and sengon woods.

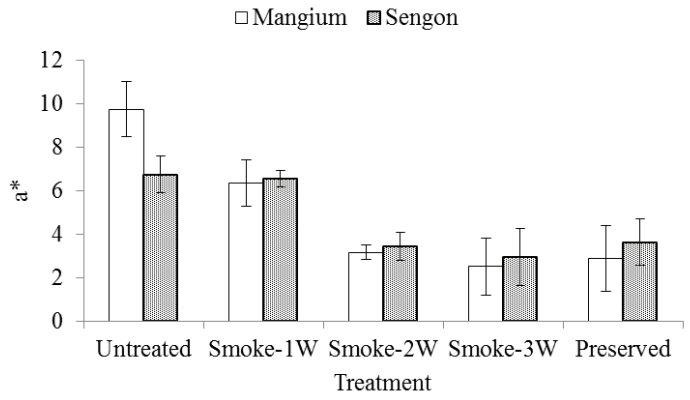

Fig. 3. The $a^{*}$ (red-green) values of mangium and sengon woods.

treatment, and interaction of both factors. Further data analysis of interaction factor (Duncan's multiple range tests) for color change is shown in Table 4. 


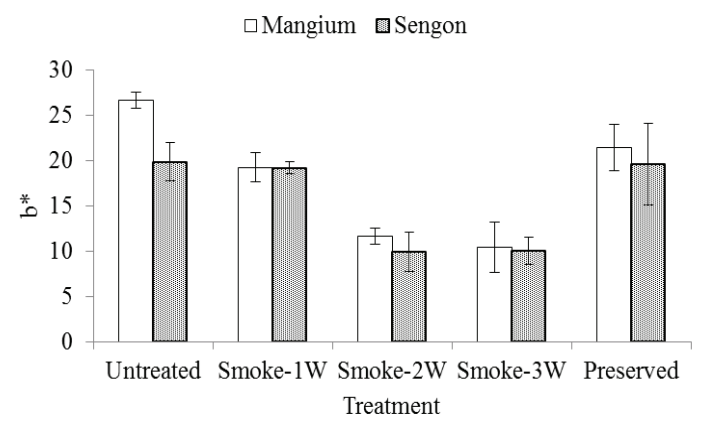

Fig. 4. The $b^{*}$ (yellow-blue) values of mangium and sengon woods.

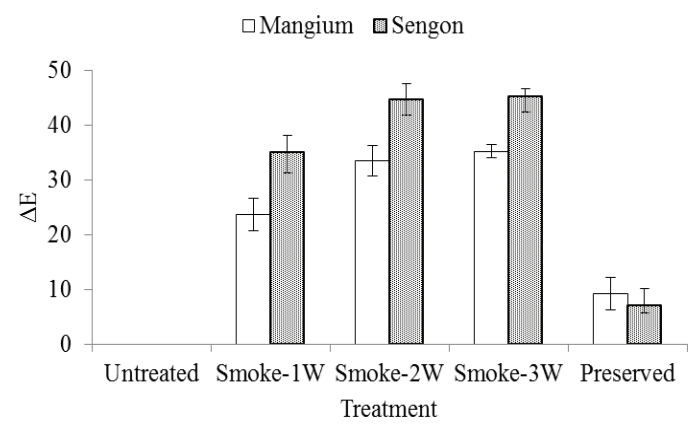

Fig. 5. The $\Delta \mathrm{E}$ (color change) values of mangium and sengon woods.

Based on data present in Table 4, smoked wood had a greater color change than imidacloprid-preserved wood. It was a darker color as indicated by the much lower $\mathrm{L}^{*}$ values. Among the smoked wood samples, the color change associated with the 1-week smoking period was different from that of the 2- and 3-week
Table 3. Variance analysis of color change, weight loss, mortality, and feeding rate

\begin{tabular}{ccccc}
\hline Source & $\begin{array}{c}\text { Color } \\
\text { change }\end{array}$ & $\begin{array}{c}\text { Weight } \\
\text { loss }\end{array}$ & Mortality & $\begin{array}{c}\text { Feeding } \\
\text { rate }\end{array}$ \\
\hline \hline Wood species & $* *$ & $* *$ & $\mathrm{~ns}$ & $\mathrm{~ns}$ \\
Treatment & $* *$ & $* *$ & $* *$ & $* *$ \\
Interaction & $* *$ & $* *$ & $\mathrm{~ns}$ & $\mathrm{~ns}$ \\
\hline$* * \mathrm{p}<0.01 ; \mathrm{ns}$, not significant.
\end{tabular}

smoking periods. The samples from the latter two periods did not differ from each other but had darker colors than the 1-week samples, as indicated by the lower $\mathrm{L}^{*}$ values. In terms of wood species, the color change of sengon wood had a higher value than mangium for the smoking process, but the two types of wood did not differ in color when preserved with imidacloprid. According to Toledo (2008), smoke could cause color changes because of the presence of phenol compounds that can react with carbonyls.

\subsection{Wood resistance to subterranean termite attack}

\subsubsection{Weight loss}

Results for weight loss (WL) of wood samplesis shown in Fig. 6. Untreated mangium wood was more resistant than untreated sengon wood as indicated by the lower $\mathrm{WL}$ and higher resistance class of mangium. Mangium wood had a higher density $\left(0.56 \mathrm{~g} / \mathrm{cm}^{3}\right)$ than sengon wood $\left(0.36 \mathrm{~g} / \mathrm{cm}^{3}\right)$, resulting in mangium

Table 4. Duncan's multiple range test for color change, weight loss, mortality, and feeding rate

\begin{tabular}{|c|c|c|c|c|c|c|}
\hline Respond & Wood species & Untreated & Smoke 1 & Smoke 2 & Smoke 3 & Imidacloprid \\
\hline \multirow{2}{*}{ Color change } & Mangium & No change & $23.68 b$ & $33.52 \mathrm{c}$ & $35.24 \mathrm{c}$ & $9.27 \mathrm{a}$ \\
\hline & Sengon & No change & $35.18 \mathrm{c}$ & $44.75 d$ & 45.39d & $7.20 \mathrm{a}$ \\
\hline \multirow{2}{*}{ Weight loss } & Mangium & $10.86 \mathrm{~d}$ & $2.90 \mathrm{ab}$ & $2.63 a b$ & $2.12 \mathrm{a}$ & $2.93 a b$ \\
\hline & Sengon & $19.32 \mathrm{e}$ & $5.01 \mathrm{c}$ & $3.24 \mathrm{abc}$ & $2.06 a$ & $4.59 b c$ \\
\hline \multicolumn{2}{|c|}{ Mortality } & $20.62 a$ & $100 \mathrm{~b}$ & $100 \mathrm{~b}$ & $100 \mathrm{~b}$ & $100 \mathrm{~b}$ \\
\hline \multicolumn{2}{|c|}{ Feeding rate } & $41.96 \mathrm{c}$ & $21.18 b$ & 16.03ab & $12.39 a$ & $20.89 b$ \\
\hline
\end{tabular}

Note: Values followed by the same letter in a column are not statistically different. 
Color Change and Resistance to Subterranean Termite Attack of Mangium (Acacia mangium) and Sengon (Falcataria moluccana) Smoked Wood

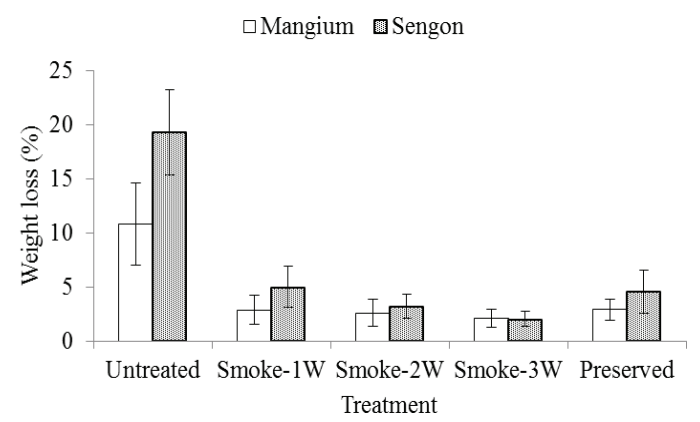

Fig. 6. Weight loss of mangium and sengon woods.

potentially being more resistant than sengon. In a previous study, Arango et al. (2006) analyzed six hardwood species and found that wood with a higher specific gravity had more resistance to Reticulitermes flavipes Kollar termites. Mangium and sengon wood in the current study had similar resistance classes as found by Arinana et al. (2012). With regard to retention of the imidacloprid preservative, mangium reached $6.12 \mathrm{~kg} / \mathrm{m}^{3}$ and sengon $7.89 \mathrm{~kg} / \mathrm{m}^{3}$. With its lower density, sengon is usually more easily penetrated by a chemical solution because there is more void space in its structure.

The analysis of variance in Table 3 shows that wood species, treatment, and the interaction of both factors highly affected WL. Based on Duncan's multiple range test of WL in Table 4, the untreated mangium and sengon wood had the largest WL values compared to treated wood, and they were significantly different from all treated wood. These results indicate that all treatments significantly enhanced wood resistance to subterranean termite attack. Furthermore, the results show that all mangium wood samples were not significantly different from each other. In the case of sengon wood, the 3-week smoking period was associated with the lowest WL, but it was not significantly different from the 2-week smoking period.

With reference to Table 2, untreated mangium wood was classified as resistance class III, or moderately resistant, based on the WL values. However, untreated sengon wood was class $\mathrm{V}$, or very poorly resistant to subterranean termite attack. For mangium wood, all smoking periods resulted in class I resistance, or very resistant, but sengon wood required at least 2 weeks of smoking to get the same results. In other words, a 1-week smoking period for mangium and a 2-week smoking period for sengon were sufficient to obtain the best results. These results were better than those found for imidacloprid-preserved wood, which obtained resistance class II, or resistant to subterranean termite attack.

\subsubsection{Mortality}

Result for termite mortality is presented in Fig. 7, the termite mortality was much lower for untreated wood, with a rate that was approximately one-fourth that found for treated wood. These findings indicate that both the smoking treatment and imidacloprid preservation were effective in enhancing wood resistance to subterranean termite attack. According to the analysis of variance in Table 3, only treatment factor affected termite mortality, and the other factors did not. Furthermore, based on Table 4 both of smoke and preservation treatments resulted in all the termites dying. This result is in agreement with Hadi et al. (2012), who found that smoke treatment applied to sengon, sugi, and pulai wood for 2 weeks resulted in 100\%

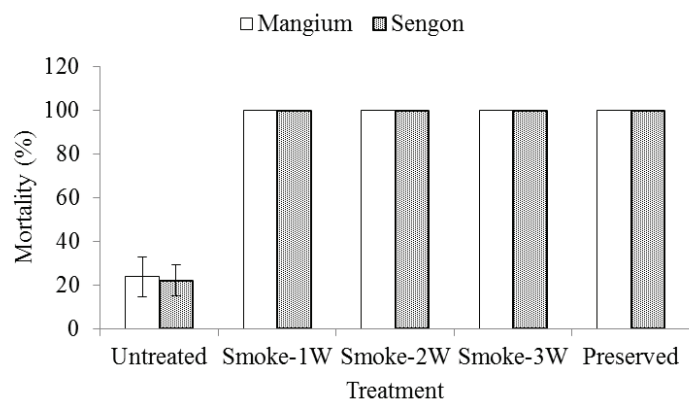

Fig. 7. Termite mortality of mangium and sengon woods. 
Yusuf Sudo HADI • Muh Yusram MASSIJAYA • Imam Busyra ABDILLAH • Gustan PARI • Wa Ode Muliastuty ARSYAD

Table 5. Wood loss, resistance class, mortality, and feeding rate for mangium and sengon wood

\begin{tabular}{|c|c|c|c|c|c|}
\hline Wood species & Treatment & WL (\%) & Resistance class & Mortality (\%) & $\begin{array}{c}\text { Feeding rate } \\
\text { ( } \mu \mathrm{g} / \text { termite/day) }\end{array}$ \\
\hline \multirow{5}{*}{ Mangium } & Untreated & $10.86(3.78)$ & III & $23.9(9.2)$ & $41.8(13.3)$ \\
\hline & Smoke $1 \mathrm{~W}$ & $2.90(1.33)$ & I & $100(0)$ & $18.9(9.4)$ \\
\hline & Smoke $2 \mathrm{~W}$ & $2.63(1.25)$ & I & $100(0)$ & $16.6(8.0)$ \\
\hline & Smoke $3 \mathrm{~W}$ & $2.12(0.85)$ & I & $100(0)$ & 14.7 (5.9) \\
\hline & Preserved & $2.93(0.97)$ & I & $100(0)$ & $18.8(6.1)$ \\
\hline \multirow{5}{*}{ Sengon } & Untreated & 19.32 (3.91) & V & $22.3(7.2)$ & $42.11(6.7)$ \\
\hline & Smoke $1 \mathrm{~W}$ & $5.01(1.90)$ & II & $100(0)$ & $23.5(7.8)$ \\
\hline & Smoke $2 \mathrm{~W}$ & $3.24(1.10)$ & I & $100(0)$ & $15.2(5.1)$ \\
\hline & Smoke $3 \mathrm{~W}$ & $2.06(0.72)$ & I & $100(0)$ & 10.1 (3.6) \\
\hline & Preserved & $4.59(1.98)$ & II & $100(0)$ & $23.0(10.7)$ \\
\hline
\end{tabular}

Notes: Values in parentheses are standard deviation.

termite mortality at the end of the experiment. The presence of acetic acid and phenolic compounds in the smoke has been suggested to increase wood resistance to subterranean termite attack (Oramahi et al., 2014).

\subsubsection{Feeding rate}

The daily termite feeding rate or daily wood consumption of each termite is shown at Fig. 8. The daily termite feeding rate reached $41.82 \pm 13.29 \mu$ g/termite for untreated sengon, which was lower than for untreated mangium, with $42.11 \pm 6.66 \mu \mathrm{g} /$ termite. These results were similar to those of Arinana et al. (2012), but lower than those of Hadi et al. (2014).

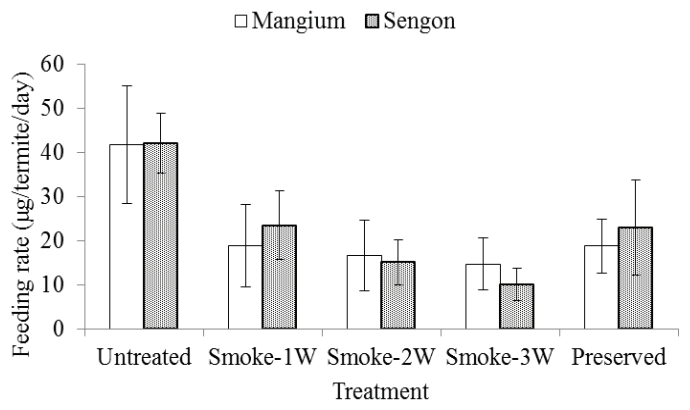

Fig. 8. Termite feeding rate of mangium and sengon woods.
According to the analysis of variance in Table 3, only the treatment factor affected the termite feeding rate; the other factors did not have an effect on it. Based on the Fig. 8, it could be mentioned that both of smoke and preservation treatments substantially reduced the termite feeding rate. Untreated wood clearly had the highest daily feeding rate, while wood smoked for 3 weeks had the lowest. The rates for other samples were between these extremes. The daily feeding rate was determined by mass (g) loss and the number of living termites, with the assumption that the termites died linearly over time. However, this assumption was not based on observation, and for future research, methods are needed on how to recognize living termites at any time during an experiment.

\section{CONCLUSION}

Based on the findings in this work, we were able to make the following conclusions:

1. The main chemical compounds of salam liquid smoke were acetic acid, phenol, ketone, benzene, and aldehyde.

2. Compared to untreated wood, smoked wood was 
Color Change and Resistance to Subterranean Termite Attack of Mangium (Acacia mangium) and Sengon (Falcataria moluccana) Smoked Wood

a different color $(\Delta \mathrm{E}>12)$ and imidaclopridpreserved wood showed a distinct color change $(6<\Delta \mathrm{E}<12)$. In addition, a longer smoking period resulted in darker color of wood, as indicated by the lower $\mathrm{L}^{*}$ values. The 2- and 3-week smoking periods yielded similar colors, which were significantly different from the lighter colors associated with the 1-week smoking period.

3. Untreated mangium wood, with a density of 0.56 $\mathrm{g} / \mathrm{cm}^{3}$ and resistance class III, was more resistant than untreated sengon wood, with a density of $0.36 \mathrm{~g} / \mathrm{cm}^{3}$ and resistance class $\mathrm{V}$.

4. Smoking treatment enhanced wood resistance to subterranean termite attack. A smoking period of 1 week for mangium and 2 weeks for sengon resulted in resistance class I wood, that is, very resistant to subterranean termite attack. These results were better than those for imidaclopridpreserved wood, which was in average resistance class II, or resistant to subterranean termite attack.

\section{ACKNOWLEDGMENT}

This research was a part of Competency Research 2019 Granted by the Ministry of Research, Technology, and Higher Education of the Indonesian Republic, and to Directorate General Research Strengthening and Development (Ditjen Penguatan Riset dan Pengembangan Kemenristekdikti) to attend 12th International Conference Wood Science and Engineering, Brasov, Romania, November 2019 via Program Bantuan Seminar Luar Negeri.

\section{REFERENCES}

Arango, R.A., Green, F., Hintz, K., Lebow, P.K., Miller, R.B. 2006. Natural durability of tropical and native woods against termite damage by Reticulitermes flavipes (Kollar). International Biodeterioration \&
Biodegradation 57(3): 146-150, doi.org/10.1016/j.ibiod.2006.01.007

Arinana, A., Tsunoda, K., Herliyana, E.N., Hadi, Y.S. 2012. Termite-susceptible species of wood for inclusion as a reference in Indonesian standardized laboratory testing. Insects 3(2): 396-401, doi: 10.3390/insects3020396.

Christie, R.M. 2007. Colour Chemistry. The Royal Society of Chemistry, Cambridge, UK.

Fajriani, E., Rulle, J., Dlouha, J., Fournier, M., Hadi, Y.S., Darmawan, W. 2013. Radial variation of wood properties of sengon (Paraserianthes falcataria) and jabon (Anthocephalus cadamba). Journal of the Indian Academy of Wood Science 10(2): 110-117.

Hadi, Y.S., Darma, I.G.K.T., Febrianto, F., Herliyana, E.N. 1995. Acetylated rubber-wood flakeboard resistance to bio-deterioration. Forest Products Journal 45(10): 64-66.

Hadi, Y.S., Westin, M., Rasyid, E. 2005. Resistance of furfurylated wood to termite attack. Forest Products Journal 55(11): 85-88.

Hadi, Y.S., Nurhayati, T., Jasni, J., Yamamoto, H., Kamiya, N. 2010. Smoked wood as an alternative for wood protection against termites. Forest Products Journal 60(6): 496-500.

Hadi, Y.S., Nurhayati, T., Jasni, J., Yamamoto, H., Kamiya N. 2012. Smoked wood resistance to subterranean and dry wood termites attack. International Biodeterioration \& Biodegradation 70: 79-81. doi: 10.1016/j.ibiod.2011.06.010.

Hadi, Y.S., Rahayu, I.S., Danu, S. 2013. Physical and mechanical properties of methyl methacrylate impregnated jabon wood. Journal of the Indian Academy of Wood Science 10(2): 77-80. doi: 10.1007/s13196-013-0098-3.

Hadi, Y.S., Arinana, A., Massijaya, M.Y. 2014. Feeding rate as a consideration factor for successful termite wood preference tests. Wood and Fiber Science 46(4): 590-593. 
Hadi, Y.S., Massijaya, M.Y., Hermawan, D., Arinana, A. 2015. Feeding rate of termites in wood treated with borax, acetylation, polystyrene, and smoke. Journal of Indian Academy Wood Science 12(1): 74-80. DOI: 10.1007/s13196-015-0146-2.

Hadi, Y.S., Efendi, M., Massijaya, M.Y., Arinana, A., Pari, G. 2016a. Subterranean resistance of smoked glued laminated lumber made from fast-growing tree species from Indonesia. Wood and Fiber Science 48(3): 211-216.

Hadi, Y.S., Massijaya, M.Y., Arinana, A. 2016b. Subterranean termite resistance of polystyrenetreated wood from three tropical wood species. Insects 7(3): pii: 37; doi:10.3390/insects7030037.

Hadi, Y.S., Massijaya, M.Y., Zaini, L.H., Abdillah, I.B., Arsyad, W.O.M. 2018. Resistance of methyl methacrylate-impregnated wood to subterranean termite attack. Journal of the Korean Wood Science and Technology 46(6): 748-755.

Hadi, Y.S., Massijaya, M.Y., Zaini, L.H., Pari, R. 2019. Physical and Mechanical Properties of Methyl Methacrylate-Impregnated Wood from Three FastGrowing Tropical Tree Species. Journal of Korean Wood Science and Technology 47(3): 324-335. pISSN: 1017-0715 eISSN: 2233-7180; DOI: 10.5658/WOOD.2018.46.2.143

Hendrik, J., Hadi, Y.S., Massijaya, M.Y., Santoso, A. 2016. Properties of laminated panels made from fast-growing species glued with mangium tannin adhesive. BioResources 11(3): 5949-5960. DOI: 10.15376/biores.11.3.5949-5960

Hidayat, W., Qi, Y., Park, B.H., Banuwa, I.S., Febrianto, F., Kim, N.H. 2017. Color change and consumer preferences towards color of heat-treated Korean white pine and royal paulownia woods. Journal of the Korean Wood Science and Technology 45(2): 213-222. doi: 10.5658/WOOD.2017.45.2.213.

Hrčková, M., Koleda, P., Koleda, P., Barcík, S., Štefková, J. 2018. Color change of selected wood species affected by thermal treatment and sanding. BioResources 13(4): 8956-8975.

Hunter Lab. 1996. Application Note: Hunter color scale. Insight on Color 8(9): 1-4.

Ishiguri, F., Andoh, M., Yokota, S., Yoshizawa, N. 2001. Effect of smoke heating on moisture content, surface checking, and dynamic Young's modulus of sugi (Cryptomeria japonica) boxed heart timber. Mokuzai Gakkaishi 47(4): 350-357.

Ishiguri, F., Maruyama, S., Takahashi, K., Abe, Z., Yokota, S., Andoh, M., Yoshizawa, N. 2003. Extractives relating to heartwood color changes in sugi (Cryptomeria japonica) by a combination of smoke-heating and UV radiation exposure. Journal of Wood Science 49(2): 135-139.

Komariah, R.N., Hadi, Y.S., Massijaya, M.Y., Suryana, J. 2015. Physical-mechanical properties of glued laminated timber made from tropical smalldiameter logs grown in Indonesia. Journal of the Korean Wood Science and Technology 43(2): 156-167. doi: 10.5658/WOOD.2015.43.2.156.

Lestari, A.S.R.D., Hadi, Y.S., Hermawan, D., Santosa, A. 2018. Physical and mechanical properties of glued laminated lumber of pine (Pinus merkusii) and jabon (Anthocephalus cadamba). Journal of the Korean Wood Science and Technology 46(2): 143-148. doi: 10.5658/WOOD.2018.46.2.143.

Martawijaya, A., Kartasujana, I., Kadir, K., Prawira, S.A. 2004. Atlas kayu Indonesia, jilid III [Indonesian Wood Atlas]. Forest Products Research Institute, Forestry Department, Bogor, Indonesia.

Ministry of Environment and Forestry. 2018. Statistic of forestry production. Ministry of Environment and Forestry, Jakarta, Indonesia.

Oramahi, H.A., Diba, F., Nurhaida. 2014. New bio preservatives from lignocelluloses biomass bio-oil for anti termites Coptotermes curvignathus Holmgren. Procedia Environmental Science 20: 778-784. SNI 7207-2014 (Standar Nasional Indonesia, Indonesian 
Color Change and Resistance to Subterranean Termite Attack of Mangium (Acacia mangium) and Sengon (Falcataria moluccana) Smoked Wood

National Standard). 2014. Uji ketahanan kayu terhadap organisme perusak kayu [Test for resistance of wood on wood deterioration organism]. National Standardization Bureau, Jakarta, Indonesia.

Stołyhwo, A., Sikorski, Z.E. 2005. Polycyclic aromatic hydrocarbons in smoked fish: a critical review. Food Chemistry 91(2): 303-311.

Toledo, R.T. 2008. Wood smoke components and functional properties. In: DE Kramer, L. Brown, (eds.), International Smoked Seafood Conference Proceedings, March 5-6, 2007, Anchorage, AK. Alaska Sea Grant College Program, Anchorage, pp.
55-61. doi:10.4027/isscp.2008.12

Yang, B.S., Yang, J., Kim, D.Y., Kim, J.K., Hwang, W.J. Kwon, G.J. 2017. Characteristics of wood tar produced as byproduct from two types of the kiln in the manufacture of oak charcoal. Journal of the Korean Wood Science and Technology 45(6): 772786. doi: 10.5658/WOOD.2017.45.6.772.

Yang, J.F., Yang, C.H., Liang, M.T., Gao, Z.J., Wu, Y.W., Chuang, L.Y. 2016. Chemical composition, antioxidant, and antibacterial activity of wood vinegar from Litchi chinensis. Molecules 1150(21): 1-10. 